DOI: https://doi.org/10.15407/publishing2020.56.077

\title{
DEVELOPMENT OF ALGORITHMS FOR FUZZY CONTROL OF ENERGY FLOWS IN THE CONDITIONS OF UNDERGROUND IRON ORE EXTRACTION
}

\author{
O. Sinchuk*, A. Kupin**, I. Sinchuk***, I. Kozakevych****, I. Peresunko ${ }^{* * * * *}$ \\ Kryvyi Rih National University, \\ Vitaly Matusevich str, 11, Kryvyi Rih, 50027, Ukraine \\ e-mail: speet@ukr.net
}

\begin{abstract}
The urgency of developing the system of automated control of energy flows in conditions of underground mining of iron ore has been shown. The principles of implementing of mentioned approaches based on the use of fuzzy logic have been proposed using previously defined criteria and algorithms of fuzzy control. The simulating of operation of fuzzy controllers in the environment of the MatLab software package has been carried out using two-part and three-part electricity tariffs. The efficiency of fuzzy controlling systems in conditions of single-channel and multi-channel controlling has been proved. The results of the application of various automated fuzzy control strategies in conditions of mining enterprises with underground mining of iron ore using two-rate and three-rate electricity tariffs have been analyzed. Corresponding recommendations for the optimizing of industrial energy consumption have been proposed. References 12, figures 8, tables 4.
\end{abstract}

Keywords: automated control of energy flows, Fuzzy Logic, models, criteria, system, mine.

\section{Introduction}

More than $30 \%$ of the total production of iron ore is mined at underground mining enterprises (mines). Meanwhile, the cost of production, due to the deterioration of mining conditions on the increase in the depth of iron ore, is increasing. In this odious for the economy of both the mining companies themselves and the state as a whole, a significant part of the negative role belongs to the energy component of the iron ore production process, where more than $90 \%$ is electricity costs.

The directions of reduction, or more precisely the restriction of the growth rate of the electric power component in the complex of iron ore production, are known [3-5].

Meanwhile, all these known trends can be synthesized into two global drawbacks: to reduce electricity consumption, which means to reduce the payment for electricity consumed, or rather, to reduce the levels of electricity consumption, or more precisely, with considerable stability of this process, to reduce payment for it. The logic behind these statements is that increasing the depth of iron ore production does not even give pessimistic reasons for reducing electricity consumption. As for the second component - reducing payment levels - there is some positive in achieving the expected results.

Due to this moment, based on taking the number of measures at the relative stability of the levels of production of iron ore in the iron ore mines of Ukraine from 2015 to 2017, the share of electricity in the cost of production has increased [3-5]. Meanwhile, during 2017-2018 underground iron ore enterprises have achieved some achievements in the overall share of electricity in stabilizing the cost of production of iron ore. However, this trend was practically counterbalanced in 2019.

This is due to the fact that, according to the Law of Ukraine on the Electricity Market, since 2013 underground iron ore enterprises, like all other industrial enterprises, were forced to abandon the system of calculations with electricity supply based on three tariff rates (peak, half-peak, night) and switch to hourly rates. At the same time, the new payment structure was essentially reduced to two rate rates - peak and night. In this case, the format of payments between consumers and suppliers of electricity with additional cargo volumes of payments on the latter complicated. But the main thing is that consumers started paying more for the same amount of electricity consumed. This

\footnotetext{
(C) Sinchuk O., Kupin A., Sinchuk I., Kozakevych I., Peresunko I., 2020

ORCID ID: *http://orcid.org/0000-0002-7621-9979; ** http://orcid.org/0000-0001-7569-1721;

*** http://orcid.org/0000-0002-7702-4030; **** https://orcid.org/0000-0003-4472-4783;

$* * * * *$ https://orcid.org/0000-0002-4901-0061
} 
again emphasizes the imperfection of the existing tariffs.

At the same time, the companies continued to plan their electricity consumption by hours of the day. At the same time, the existing planning system is not perfect, considering the plan-fact ratio. This is evidenced by plan-fact indicators for many domestic iron ore mines, where fluctuations take place both higher than the plan and smaller, and, importantly, have significant variations. Ultimately, such a mismatch leads to a corresponding imbalance in the payment for electricity consumed. That is, in this embodiment, the lack of control over the levels of electricity consumption leads to significant unreasonable costs on the part of consumers.

The rejection, or even delay, at the start of the introduction of effective science-based measures to improve the power efficiency of mining and technological processing of iron ore, which will at least accelerate the exit of enterprises of the mining and metallurgical industry in the depressed stage of their development.

\section{Statement of the problem}

The problem of the optimizing of the energy consumption in conditions of iron ore mines based on the use of the fuzzy automated control system (ACS) using multi-zone energy metering tariffs is considered. So the urgency of the approach has been substantiated in operation [1], the system of optimization criteria (1) (5), restrictions (6) - (9) has been developed and algorithms for implementing many strategies for such controlling in conditions of the three-rate tariff ("Night / Half-Peak / Peak") have been proposed.

The technological process considerated as a control object is complex multi-parameter, nonlinear and multi-connected [2-3]. As you know, the main consumers of electricity (EE) in mines are redistribution of mining / transportation of ore mass, discharge of mine water (drainage), air supply and ventilation. [4] With this in mind, potential management criteria should be identified as (1) - (5)

$$
\begin{gathered}
\mathrm{Z}^{\mathrm{e}}=F(R E, H T) \Rightarrow \min , \\
\mathrm{P} \Rightarrow \max , \\
\mathrm{B} \Rightarrow \max , \\
\mathrm{B}_{w} \Rightarrow \max , \\
\mathrm{B}_{v} \Rightarrow \max ,
\end{gathered}
$$

where $Z^{\mathrm{e}}$ - is the total cost of the enterprise for electricity consumed (hourly, daily), UAH .; RE power consumption, $\mathrm{kW} ; H T$ - current electricity tariff, UAH / $\mathrm{kW} ; F(\bullet)$ - some established functional dependency; $\mathrm{P}$ - ore mass production at the enterprise, $\mathrm{t}$; $\mathrm{B}$ - air supply, $\mathrm{m}^{3} ; \mathrm{B}_{w}-\mathrm{mine}$ water pumping volume, $\mathrm{m}^{3} ; \mathrm{B}_{v}$-ventilation, $\mathrm{m}^{3}$.

Considering the potential complexity of solving such multicriteria problems, some of the minimax criteria above can be replaced in the future by restrictions of the type:

$$
\begin{aligned}
& \mathrm{P} \geq \mathrm{P}^{\min }, \\
& \mathrm{B} \geq \mathrm{B}^{\text {min }}, \\
& \mathrm{B}_{w} \geq \mathrm{B}_{w}^{\min }, \\
& \mathrm{B}_{v} \geq \mathrm{B}_{v}^{\min },
\end{aligned}
$$

where $\mathrm{P}^{\min }, \mathrm{B}^{\min }, \mathrm{B}_{w}^{\min }, \mathrm{B}_{v}^{\min }$ - some boundary values of the parameters (for example, daily planned values).

The value of energy consumption in the system as a whole or in separate stages from the local criterion of the objective function (1) can thus be redefined in the form

$$
R E=f\left(P, B, B_{w}, B_{v}\right),
$$

where $\mathrm{f}(\bullet)$ - some function or approximation.

The sufficient efficiency of applying of the fuzzy controlling approach in conditions of three-rate tariff creates the preconditions for its verification using the currently relevant two-zone tariff type "Night / Peak". Thus, the task of developing appropriate models, the principles of their 
phasing, logical inference, and defuzzification, as well as a testing performance by computer simulation is set.

\section{Development of fuzzy models taking into account the two-part tariff}

3.1. The principles of phasing and forming of a base of logical rules of inference in conditions of the single-channel control.

Let us analyze the principles of phasing and the formation of a base of logical inference rules for the single-channel control. The controlling effect here is the ore flow $\mathrm{P}$, the controlled parameter will be the value of the electric energy consumption from (10). The parameters of drainage, air supply, and ventilation are related to perturbing.

We define, according to the technique described in [5-7], we formalize the basic fuzzy set for our system. In our case, this set will consist of three elements $(\mathrm{N}=3)$ :

$$
\overline{\mathrm{B}}=\bigcup_{i=1}^{N}\left\{\frac{\beta_{i}}{\mu\left(\beta_{i}\right)}\right\}=\left\{\frac{\beta_{1}}{\mu\left(\beta_{1}\right)} ; \frac{\beta_{2}}{\mu\left(\beta_{2}\right)} ; \frac{\beta_{3}}{\mu\left(\beta_{3}\right)}\right\}=\left\{\frac{\beta_{R E}}{\mu\left(\beta_{R E}\right)} ; \frac{\beta_{H T}}{\mu\left(\beta_{H T}\right)} ; \frac{\beta_{P}}{\mu\left(\beta_{P}\right)}\right\},
$$

where $\overline{\mathrm{B}}$ - the basic fuzzy set; $\beta_{i}$ - fuzzy value of a specific parameter (for example, manager or managed); $\beta_{1}=\beta_{R E}$ - the corresponding fuzzy value for the energy consumption parameter; $\beta_{2}=\beta_{H T}$ - fuzzy value for the tariff; $\beta_{3}=\beta_{P}$ - fuzzy ore flow; $\mu\left(\beta_{i}\right), \mu\left(\beta_{1}\right), \mu\left(\beta_{2}\right), \mu\left(\beta_{3}\right)$, $\mu\left(\beta_{R E}\right), \mu\left(\beta_{H T}\right), \mu\left(\beta_{P}\right)$ - the value of membership functions for the corresponding parameters.

We determine the sets of linguistic variables (terms) for all of the fuzzy parameters above:

$$
\begin{aligned}
& T_{1}^{E E}=\left\{\frac{M I N}{N B} ; \frac{\text { Average }}{\mathrm{Z}} ; \frac{M A X}{P B}\right\}, \\
& T_{2}^{\text {Tariff }}=\left\{\frac{\text { Night }}{\mathrm{NS}} ; \frac{\text { Peak }}{\mathrm{PS}}\right\}, \\
& T_{3}^{\text {Ore }}=\left\{\frac{M I N}{N B} ; \frac{\text { Average }}{\mathrm{Z}} ; \frac{M A X}{P B}\right\},
\end{aligned}
$$

where $T_{1}^{E E}, T_{2}^{\text {Tariff }}, T_{3}^{\text {Ore }}$ - identifiers of multiple terms for fuzzy variables: energy consumption (EE), tariff setting and ore flow; $\{$ MIN, average, MAX $\}+\{$ Night, Peak $\},\{N B, Z, P B\}+\{N S, P S\}$ full or abbreviated identifiers to indicate the corresponding values of these terms.

As can be seen from the sets (11) - (14), the three-digit scale is taken for subsequent work by the parameters of energy consumption and ore flow and for the variable tariff - two-digit. However, if necessary, the quantitative values of all these scales can be changed in any direction.

Subsequently, for the implementation of the fuzzification of fuzzy variables of the set (12) and (14), standard triangular membership functions have been chosen, and for the set (13) has been chosen tangential. An example of the parameterization of these variables and functions has been performed using the environment of the MATLAB application. The example of such parameterization based on statistics from the Rodina mine is shown in Fig.1.
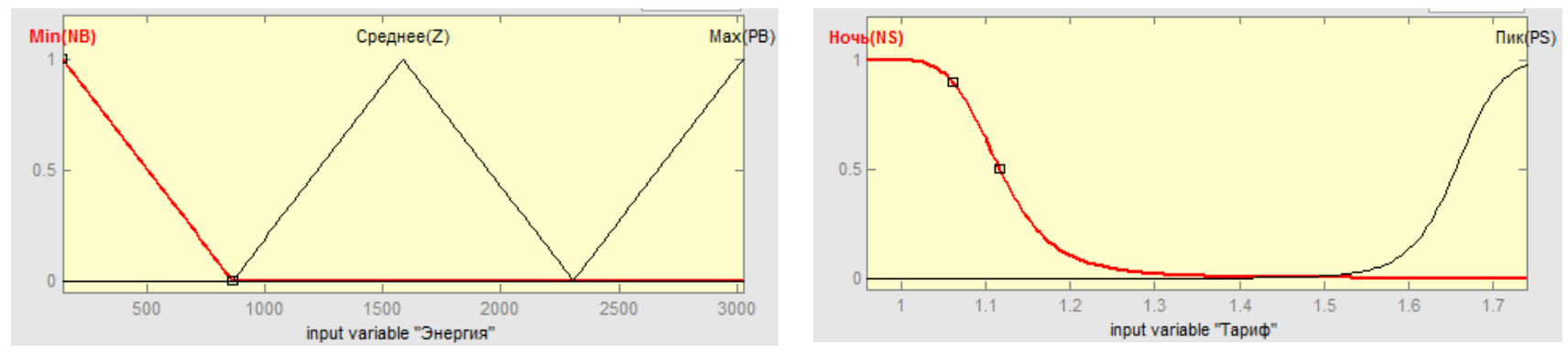

Fig. 1 
We previously defined fuzzy sets (11) and the corresponding terms (12) - (14), we will form fuzzy inference rules in the form:

1) IF "Electric Energy Consumption" = "MIN" (NB) AND "Tariff" = "Peak" (PS) THEN "Oreflow" = "MIN" (NB);

2) IF "Electric Energy Consumption" = "MAX" (PB) AND "Tariff" = "Night" (NS) THEN "Oreflow" = "MAX" (PB);

3) IF "Electric Energy Consumption" = "Average" (Z) AND "Tariff" = "Night" (NS) THEN "Oreflow" = "MAX" (PB);

4) IF "Electric Energy Consumption" = "Average" (Z) AND "Tariff" = "Peak" (PS) THEN "Oreflow" = "MIN" (NB);

5) IF "Electric Energy Consumption" = "MIN" (NB) AND "Tariff" = "Night" (NS) THEN "Oreflow" = "MAX" (PB);

6) IF "Electric Energy Consumption" = "MAX" (PB) AND "Tariff" = "Peak" (PS) THEN "Oreflow" = "MIN" (NB).

Table 1

\begin{tabular}{|l|c|c|c|}
\hline \multirow{2}{*}{ Tariff [Oreflow] } & \multicolumn{3}{|c|}{ Electric Energy Consumption } \\
\cline { 2 - 4 } & MIN (NB) & Average $(\mathrm{Z})$ & MAX (PB) \\
\hline Peak (PS) & {$[N B]$} & {$[N B]$} & {$[N B]$} \\
\hline Night (NS) & {$[P B]$} & {$[P B]$} & {$[P B]$} \\
\hline
\end{tabular}

As the basic algorithm for the subsequent defuzzification procedure, we adopt the standard Mamdani method.

\subsection{The principles of phasing and forming of a base of logical inference rules in conditions of the three-channel control.}

This type of control is implemented by two or three control actions (11). For example, Ore + Drainage + Ventilation. The control actions here are ore flow and the volume of water pumping and ventilation, a controlled parameter will be the value of electricity consumption from (10). The air supply parameter remains perturbing. The general principles of phasing and the formation of a base of logical inference rules for the three-channel control are as follows.

Basic fuzzy set (16) for the possibility of implementing of the three-channel control. In our case, this set will include 5 elements now $(\mathrm{N}=5)$ :

$$
\begin{aligned}
& \overline{\mathrm{B}}=\bigcup_{i=1}^{N}\left\{\frac{\beta_{i}}{\mu\left(\beta_{i}\right)}\right\}=\left\{\frac{\beta_{1}}{\mu\left(\beta_{1}\right)} ; \frac{\beta_{2}}{\mu\left(\beta_{2}\right)} ; \frac{\beta_{3}}{\mu\left(\beta_{3}\right)} ; \frac{\beta_{4}}{\mu\left(\beta_{4}\right)} ; \frac{\beta_{5}}{\mu\left(\beta_{5}\right)}\right\}= \\
& =\left\{\frac{\beta_{R E}}{\mu\left(\beta_{R E}\right)} ; \frac{\beta_{H T}}{\mu\left(\beta_{H T}\right)} ; \frac{\beta_{P}}{\mu\left(\beta_{P}\right)} ; \frac{\beta_{B w}}{\mu\left(\beta_{B w}\right)} ; \frac{\beta_{B v}}{\mu\left(\beta_{B v}\right)}\right\}
\end{aligned}
$$

where $\beta_{5}=\beta_{B v}$ - the fuzzy value for drainage; $\mu\left(\beta_{5}\right), \mu\left(\beta_{B v}\right)$ - corresponding to the value of the membership function.

Then, to the sets of terms already defined above (11-14), you need to additionally define the terms:

$$
\begin{array}{r}
T_{4}^{\text {Water }}=\left\{\frac{M I N}{N B} ; \frac{\text { Average }}{\mathrm{Z}} ; \frac{M A X}{P B}\right\}, \\
T_{5}^{\text {Ventilation }}=\left\{\frac{M I N}{N B} ; \frac{\text { Average }}{\mathrm{Z}} ; \frac{M A X}{P B}\right\},
\end{array}
$$

where $T_{4}^{\text {Water }}$ - the term identifier for the fuzzy variable volume of water pumping; $T_{5}^{\text {Ventilation }}$ - term identifier for the fuzzy variable mine ventilation volume.

In view of (15) - (17), we give a few examples of the formation of fuzzy inference rules for this type of control: 
1) IF "Power Consumption" $\left(\beta_{1}\right)=$ "MIN" (NB) AND "Tariff" $\left(\beta_{2}\right)=$ "Peak" (PS) THEN "Oreflow" = "MIN" (NB), "Drainage" = "MIN" (NB), "Ventilation" = "MIN" (NB);

2) IF "Electric Energy Consumption" $\left(\beta_{1}\right)=$ "MAX" (PB) AND "Tariff" $\left(\beta_{2}\right)=$ "Night" (NS) THEN "Ore Flow" = "MAX" (PB), "Drainage" = "MAX" (PB), "Ventilation" = "MAX" (PB);

3) IF "Electric Energy Consumption" $\left(\beta_{1}\right)=$ "Average" (Z) AND "Tariff" $\left(\beta_{2}\right)=$ "Night" (NS) THEN "Oreflow" = "MAX" (PB), "Drainage" = "MAX" (PB), "Ventilation" = "MAX" (PB);

4) IF "Electric Energy Consumption" = "Average" (Z) AND "Tariff" = "Peak" (PS) THEN "Oreflow" = "MIN" (NB), "Drainage" = "MIN" (NB), "Ventilation" = "MIN" (NB);

5) IF "Electric Energy Consumption" = "MIN" (NB) AND "Tariff" = "Night" (NS) THEN "Oreflow" = "MAX" (PB), "Drainage" = "MAX" (PB), "Ventilation" = "MAX" (PB);

6) IF "Electric Energy Consumption" = "MAX" (PB) AND "Tariff" = "Peak" (PS) THEN "Oreflow" = "MIN" (NB), "Drainage" = "MIN" (NB), "Ventilation" = "MIN" (NB).

Extended tables (Tab. 2, Tab. 3) of inferences for fuzzy variables (16), (17) shown below. For a boolean variable ore flow $\beta_{3}=\beta_{P}$ a similar table Tab. 1 can be used, which was given above.

Table 2

\begin{tabular}{|l|c|c|c|}
\hline \multirow{2}{*}{ Tariff $[$ Oreflow] } & \multicolumn{3}{|c|}{ Drainage } \\
\cline { 2 - 4 } & MIN (NB) & Average (Z) & MAX (PB) \\
\hline Peak (PS) & {$[N B]$} & {$[N B]$} & {$[N B]$} \\
\hline Night (NS) & {$[P B]$} & {$[P B]$} & {$[P B]$} \\
\hline
\end{tabular}

Table 3

\begin{tabular}{|l|c|c|c|}
\hline \multirow{2}{*}{ Tariff [Oreflow] } & \multicolumn{3}{|c|}{ Ventilation } \\
\cline { 2 - 4 } & MIN (NB) & Average $(\mathrm{Z})$ & MAX (PB) \\
\hline Peak (PS) & {$[N B]$} & {$[N B]$} & {$[N B]$} \\
\hline Night $(\mathrm{NS})$ & {$[P B]$} & {$[P B]$} & {$[P B]$} \\
\hline
\end{tabular}

\section{Computer simulation of the operation of fuzzy ACS}

To simulate the operation of the ACS of mine energy consumption, we will use the environment of the Fuzzy Logic Toolbox (FLT) module from the well-known mathematical software package MATLAB. To do this, we use the standard fuzzy simulating technique described in [7].

4.1. Simulating of the single-channel control. The forming of a fuzzy controller will be carried out using the example of the single-channel control via the Rudopotok-> Energy Consumption channel based on statistics from the data received at Rodina mine (Kryvyi Rih, Tab. 4). Taking into account the fuzzy variables defined above, fuzzy sets (11) - (14), and membership functions (Fig. 1), the input and output parameters are set in the FIS editor (Fig. 2). For defuzzification the Mamdani algorithm will be used $[8,9]$.

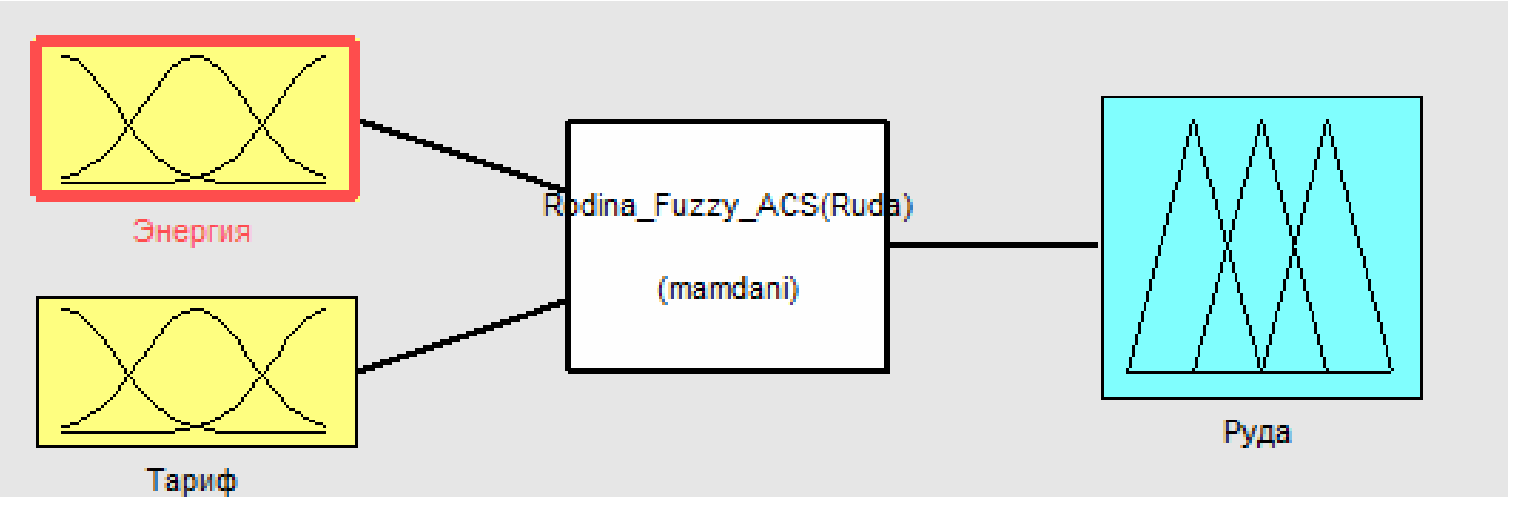

Fig. 2 
Table 4

\begin{tabular}{|c|c|c|c|c|c|c|}
\hline $\begin{array}{c}\text { Times of } \\
\text { day }\end{array}$ & $\begin{array}{c}\text { 1.Power } \\
\text { consumption, } \\
\mathrm{kW}\end{array}$ & 2.Ore, $\mathrm{t}$ & $\begin{array}{c}\mathrm{EE} \\
\text { consumption } \\
\text { forecast }\end{array}$ & $\begin{array}{l}\mathrm{ACS} \\
\text { reaction } \\
(\mathrm{FLC})\end{array}$ & $\begin{array}{c}\text { Energy cost } \\
\text { (without ACS), } \\
\text { UAH }^{*}\end{array}$ & $\begin{array}{l}\text { Energy cost (with } \\
\text { ACS), UAH* }\end{array}$ \\
\hline $0: 00$ & 1824 & 132 & 2034,64 & 147 & 1751,04 & 1953,26 \\
\hline $0: 30$ & 3024 & 219 & 2795,86 & 202 & 2903,04 & 2684,03 \\
\hline $1: 00$ & 2688 & 194 & 2795,86 & 202 & 2580,48 & 2684,03 \\
\hline $1: 30$ & 2976 & 215 & 2795,86 & 202 & 2856,96 & 2684,03 \\
\hline $2: 00$ & 2736 & 198 & 2795,86 & 202 & 2626,56 & 2684,03 \\
\hline $2: 30$ & 2976 & 215 & 2795,86 & 202 & 2856,96 & 2684,03 \\
\hline $3: 00$ & 2976 & 215 & 2795,86 & 202 & 2856,96 & 2684,03 \\
\hline $3: 30$ & 1968 & 142 & 2090 & 151 & 1889,28 & 2006,40 \\
\hline $4: 00$ & 144 & 10 & 2795,86 & 202 & 138,24 & 2684,03 \\
\hline $4: 30$ & 2400 & 173 & 2795,86 & 202 & 2304,00 & 2684,03 \\
\hline $5: 00$ & 1440 & 104 & 2006,96 & 145 & 1382,40 & 1926,68 \\
\hline $5: 30$ & 1248 & 90 & 2076,16 & 150 & 1198,08 & 1993,12 \\
\hline $6: 00$ & 192 & 14 & 2795,86 & 202 & 184,32 & 2684,03 \\
\hline $6: 30$ & 192 & 14 & 2795,86 & 202 & 184,32 & 2684,03 \\
\hline $7: 00$ & 192 & 14 & 2795,86 & 202 & 184,32 & 2684,03 \\
\hline $7: 30$ & 192 & 14 & 2795,86 & 202 & 184,32 & 2684,03 \\
\hline $8: 00$ & 144 & 10 & 2795,86 & 202 & 138,24 & 2684,03 \\
\hline $8: 30$ & 192 & 14 & 2795,86 & 202 & 184,32 & 2684,03 \\
\hline 9:00 & 192 & 14 & 372,415 & 26,9 & 334,08 & 648,00 \\
\hline $9: 30$ & 192 & 14 & 372,415 & 26,9 & 334,08 & 648,00 \\
\hline $10: 00$ & 192 & 14 & 372,415 & 26,9 & 334,08 & 648,00 \\
\hline $10: 30$ & 192 & 14 & 372,415 & 26,9 & 334,08 & 648,00 \\
\hline $11: 00$ & 144 & 10 & 372,415 & 26,9 & 250,56 & 648,00 \\
\hline $11: 30$ & 192 & 14 & 372,415 & 26,9 & 334,08 & 648,00 \\
\hline 12:00 & 1776 & 128 & 1150,24 & 83,1 & 3090,24 & 2001,42 \\
\hline $12: 30$ & 2880 & 208 & 372,415 & 26,9 & 5011,20 & 648,00 \\
\hline $13: 00$ & 1296 & 94 & 1121,18 & 81 & 2255,04 & 1950,85 \\
\hline $13: 30$ & 2592 & 187 & 372,415 & 26,9 & 4510,08 & 648,00 \\
\hline $14: 00$ & 2640 & 191 & 372,415 & 26,9 & 4593,60 & 648,00 \\
\hline $14: 30$ & 2016 & 146 & 1042,29 & 75,3 & 3507,84 & 1813,58 \\
\hline $15: 00$ & 1200 & 87 & 1075,51 & 77,7 & 2088,00 & 1871,38 \\
\hline $15: 30$ & 144 & 10 & 372,415 & 26,9 & 250,56 & 648,00 \\
\hline $16: 00$ & 1536 & 111 & 1169,62 & 84,5 & 2672,64 & 2035,14 \\
\hline $16: 30$ & 2688 & 194 & 372,415 & 26,9 & 4677,12 & 648,00 \\
\hline $17: 00$ & 1824 & 132 & 1137,79 & 82,2 & 3173,76 & 1979,75 \\
\hline $17: 30$ & 2160 & 156 & 870,668 & 62,9 & 3758,40 & 1514,96 \\
\hline 18:00 & 2496 & 180 & 372,415 & 26,9 & 4343,04 & 648,00 \\
\hline $18: 30$ & 1632 & 118 & 1169,62 & 84,5 & 2839,68 & 2035,14 \\
\hline
\end{tabular}




\begin{tabular}{|c|c|r|r|r|r|r|}
\hline $19: 00$ & 192 & 14 & 372,415 & 26,9 & 334,08 & 648,00 \\
\hline $19: 30$ & 144 & 10 & 372,415 & 26,9 & 250,56 & 648,00 \\
\hline $20: 00$ & 192 & 14 & 372,415 & 26,9 & 334,08 & 648,00 \\
\hline $20: 30$ & 192 & 14 & 372,415 & 26,9 & 334,08 & 648,00 \\
\hline $21: 00$ & 192 & 14 & 372,415 & 26,9 & 334,08 & 648,00 \\
\hline $21: 30$ & 144 & 10 & 372,415 & 26,9 & 250,56 & 648,00 \\
\hline $22: 00$ & 192 & 14 & 372,415 & 26,9 & 334,08 & 648,00 \\
\hline $22: 30$ & 192 & 14 & 372,415 & 26,9 & 334,08 & 648,00 \\
\hline $23: 00$ & 192 & 14 & 372,415 & 26,9 & 334,08 & 648,00 \\
\hline $23: 30$ & 1776 & 128 & 2020,8 & 146 & 1704,96 & 1939,97 \\
\hline Total & $\mathbf{5 8 8 9 6}$ & $\mathbf{4 2 5 5}$ & $\mathbf{6 5 9 2 8 , 3}$ & $\mathbf{4 7 6 3 , 1}$ & $\mathbf{7 9 6 4 0 , 6 4}$ & $\mathbf{7 6 2 0 6 , 1 1}$ \\
\hline
\end{tabular}

Note: $(*)$ - calculation of the cost of energy efficiency based on a 2-rate tariff [10].

In the process of phasing, the corresponding maximum and minimum daily parameters have been determined:

- power consumption $(144 ; 3024) \mathrm{kW} /$ day;

- ore mining $(10 ; 219) \mathrm{t} /$ day.

Based on such data, a $3 \mathrm{~d}$ model of the surface has been obtained for fuzzy inference for the developed fuzzy model (Fig. 3).

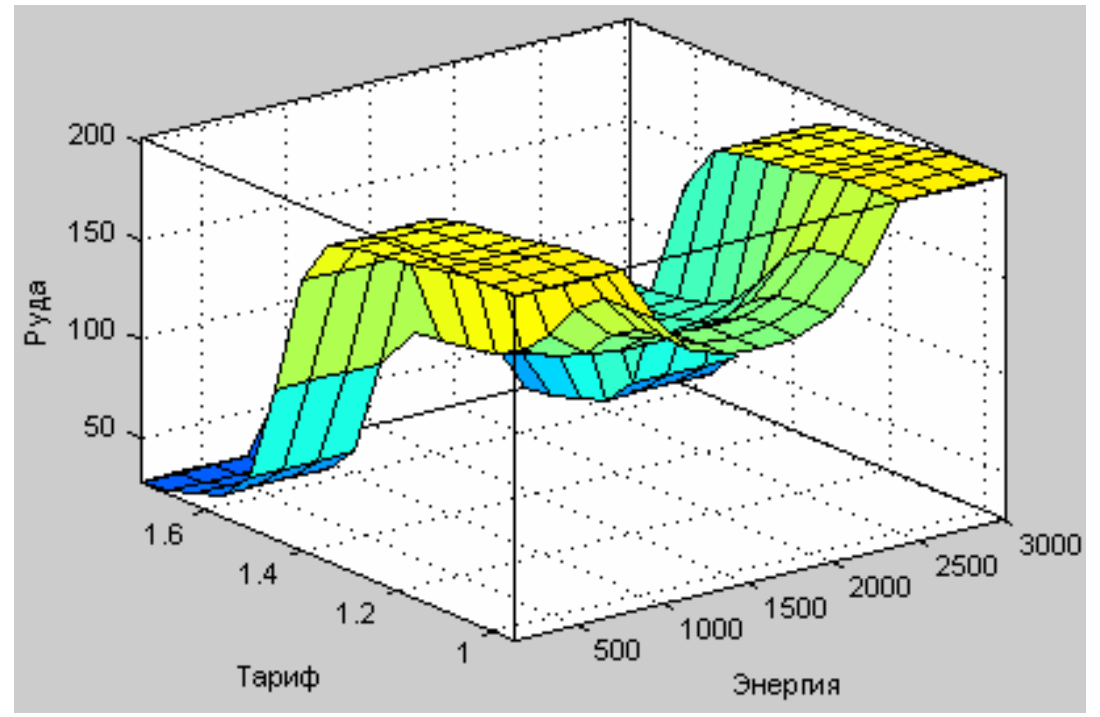

Fig. 3
Using the appropriate MATLAB FLT mode for simulating of fuzzy inference procedures, we verify the operation of the model and then calculate the expected fuzzy controller response to control actions. In this case, different values of the two-zone tariff for consumed electricity are used. The current data for DTEK Dneproblenergo (for industrial consumers of the 1st category) have been taken as base tariffs (Fig. 4) [10].
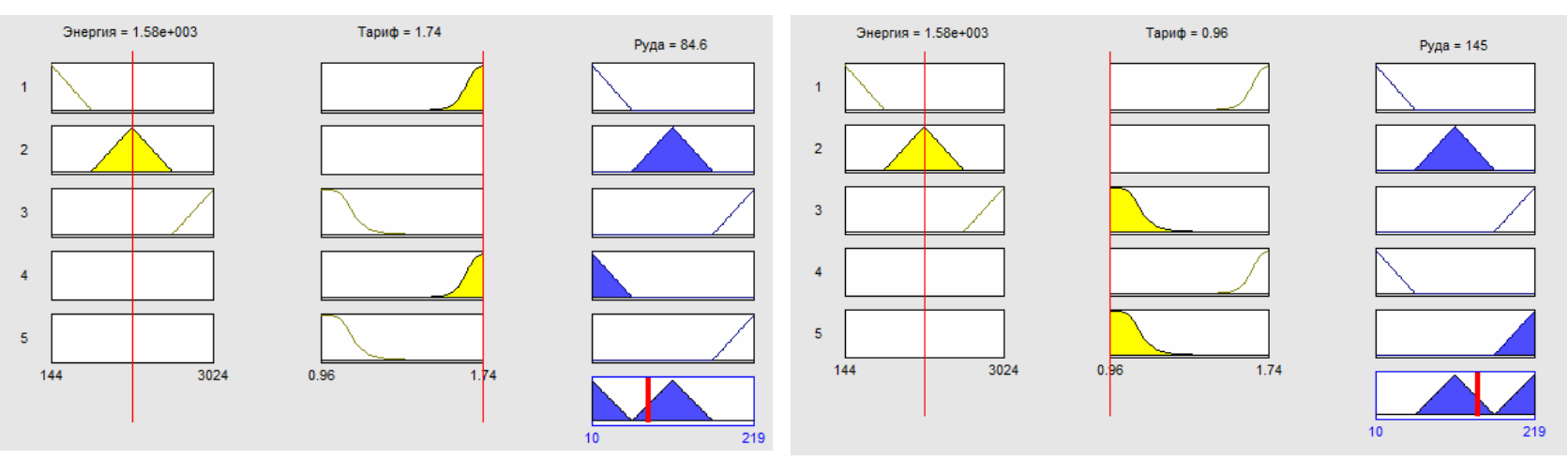

Fig. 4 
Fig. 5 and Fig. 6 show the results of simulating the operation of the fuzzy single-channel ACS of energy consumption based on one control action - daily ore production distributed over time. The simulating resolution of the controller has been 0.5 hours $=30$ minutes.

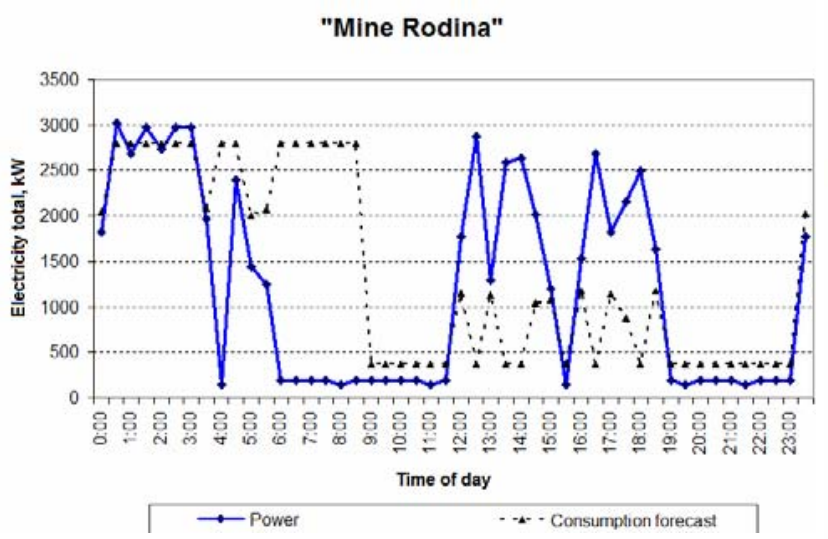

(1)

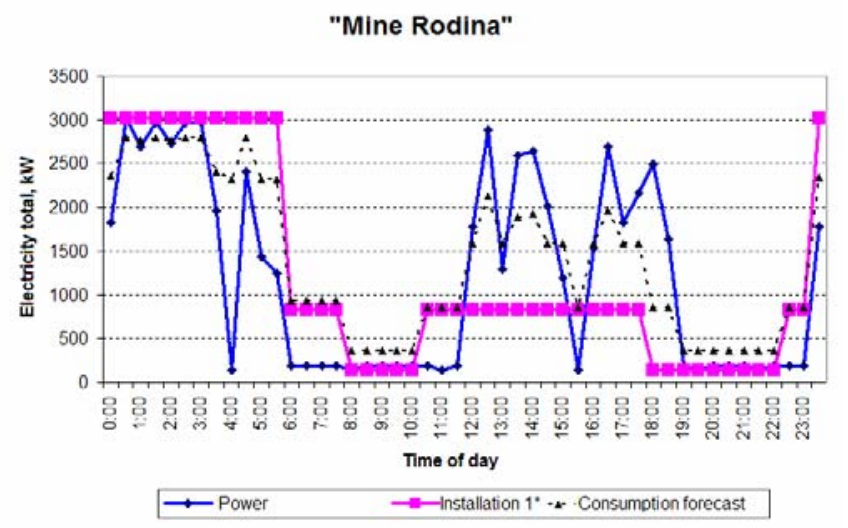

(2)

Fig. 5

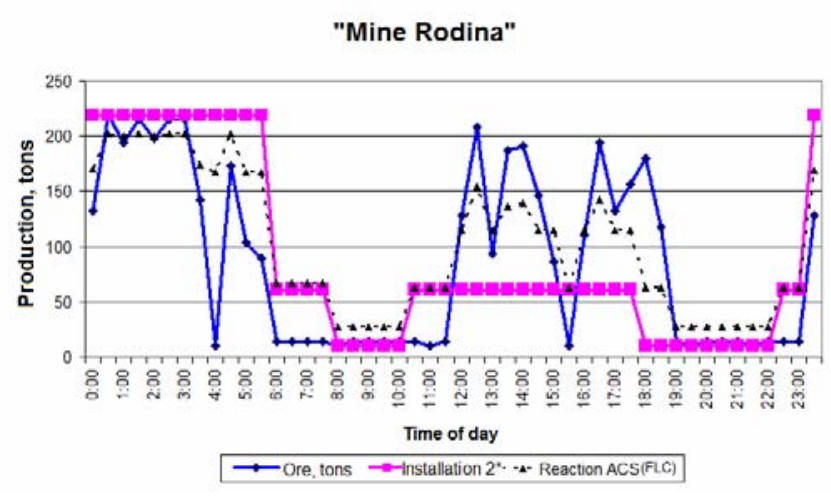

(1)

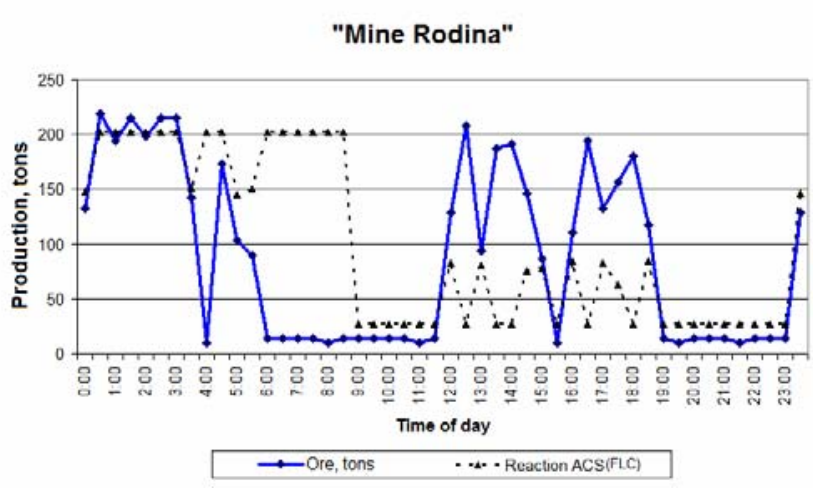

(2)

Fig. 6

Analysis of the simulation results Fig. 7 and Fig. 8 and the performed analytical calculations show that the use of minimax criteria of the type (1) - (2) in conditions of the Rodina mine allows increasing the daily ore mining by $14.85 \%$ (i.e., more than 600 tons/day). At the same time, daily electricity consumption will similarly increase by $14.86 \%$ [1], and the cost of using electricity, taking into account the three-zone tariff, will increase by $10.83 \%$. However, at the current value of salable iron ore in the world market [11-12], this may be offset by potential sales income.
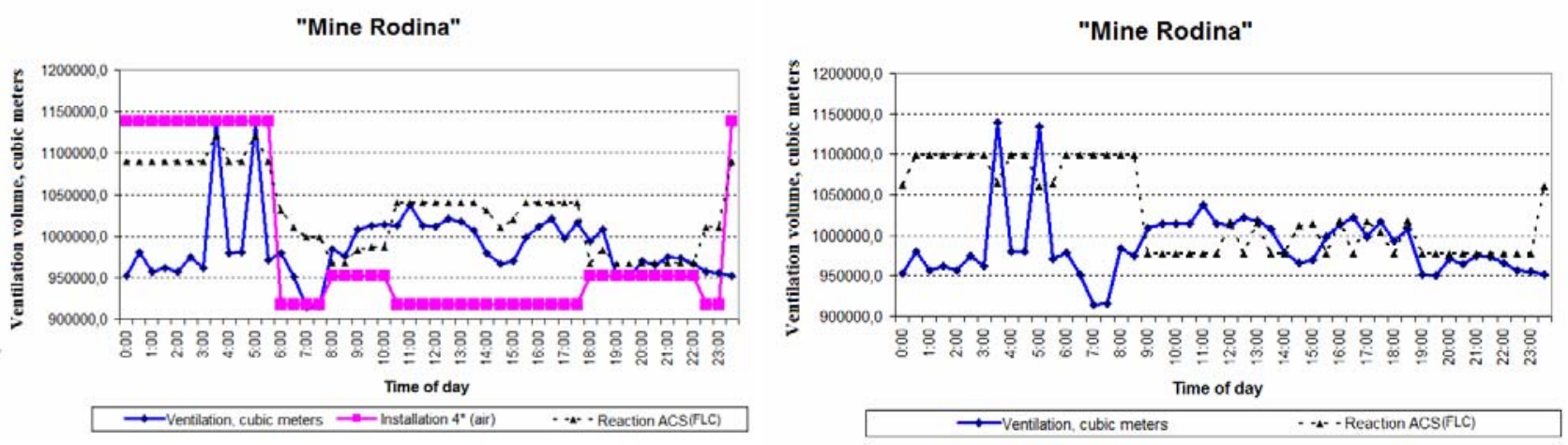

(1)

Fig. 7

(2) 


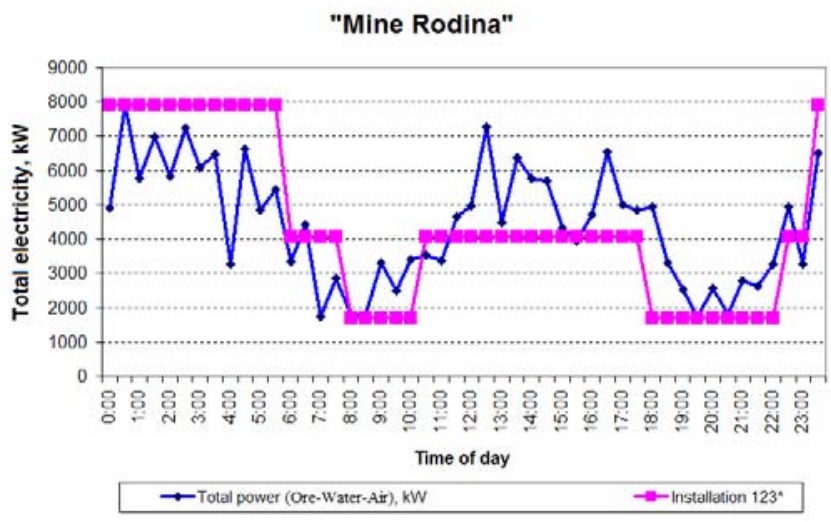

(1)

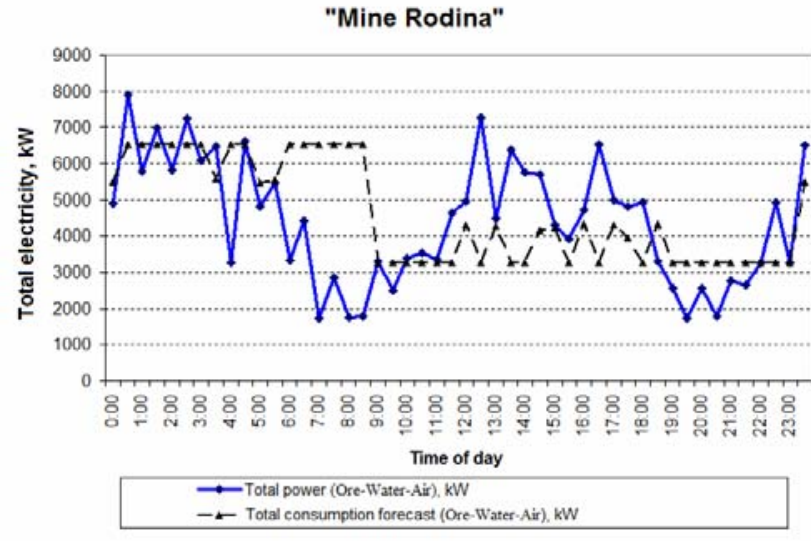

(2)

Fig. 8

4.2. Simulating of the multi-channel control. The basic principles of the forming of fuzzy controllers (including phasing, fuzzy inference, dephasing, etc.), as well as the algorithms of their operation in conditions of multi-channel control, have been described above. We present the results of the simulating of automated energy control using the example of two channels ("Ore ...", "Water ...") and three channels ("Ore ...", "Water ...", "Air ..."). The basic calculations have been carried out using the statistics of the Rodina mine as an example. However, as the made analysis testifies using this methodology, these results can be similarly reproduced for all strategies of algorithms (Figs. 2 and 3 ) and in conditions of other enterprises (mines) with underground mining of iron ore.

Conclusions. 1. Using the Fuzzy Logic Toolbox software module of the MATLAB software package, single and multi-channel fuzzy controllers have been developed and simulated for controlling the mine energy consumption by applying one or more control actions \{"Ore", "Water", "Air" \}. It was found that the use of minimax strategy in all cases leads to increasing: daily ore production and EE consumption by $15-50 \% \%$ and corresponding costs by $11-75 \%$. At the same time, calculations have shown that the potential income from the sale of additional volume of iron ore will fully compensate for these costs (due to a more rational redistribution of material and energy flows in the conditions of the 3-zone tariff). Using of the two-rate ("Night / Peak") tariff instead of the three-rate ("Night / Half-peak / Peak") at the same time leads to increasing of the daily cost of energy consumption by $12.88 \%$ at the single-channel regulation of ore flow and, accordingly, $7.1 \%$ at the two-channel management of ore flow and the drainage simultaneously. The applying of the fuzzy regulators allows to compensate for these losses. 3. Using of automated control systems by fuzzy 3-channel regulation of ore flow, drainage and ventilation allow even in conditions of the two-rate tariff (due to a more rational redistribution of daily intervals) to reduce the cost of energy efficiency (for example, according to the Rodina mine, with an increase in daily energy consumption by $4.45 \%$; total costs are reduced by $2.5 \%$ ). 4 . Applying these approaches will allow to implement automated control of the process of mine energy consumption in real-time and optimize the cost of energy efficiency.

1. Sinchuk O., Kupin A., Sinchuk I., Kozakevich I., Dozorenko O. Optimization of energy consumption in conditions of iron ore mines based on the use of fuzzy logic. Electricity and energy-saving systems. Kremenchuk: KrNU, 2019.Edition.3. 2019 (47). Pp.58-65. (Eng)

2. Denisov A. Theory of large control systems. A.Denisov, D.Kolesnikov. L.: Energy Publishing House. Leningrad Department, 1982. 287 p. (Rus)

3. Molchanov A. Modeling and design of complex systems. Molchanov A., K.: High school, 1988. Pp. 359. (Rus)

4. Meerov M. Multiply connected control systems. M. Meerov, A. Akhmetzyanov, Y. Bershchansky, etc.; under the editorship of M. Meerova., M : Nauka, 1990 . 264 p. (Rus)

5. Dorf R. Modern control systems. R. Dorf, R. Bishop; Trans. from English. M.: Laboratory of Basic Knowledge, 2004. 832 p. (Eng)

6. Kupin A. Intellectual identification and control in conditions of processes of enrichment technology: Monograph. A. Kupin. Krivoy Rog: KTU. 2008. 204 p. (Ukr) 
7. Leoninkov A. Fuzzy modeling in MATLAB and fuzzy TECH., A. Leoninkov. SPb.: BHV-S.Peterburg, 2003. 736 p. (Rus)

8. Bodiansky E. Methods of computational intelligence in control systems for control of technological processes of ferroalloy production. Bodiansky E., Kuchenrenko E., Mikhalev O., Filatov V., Gasik M. Monograph (Scientific Edition). Dnepropetrovsk: NMetAU, 2011. 420 p. (Ukr)

9. Kupin, A., Senko, A. Principles of intellectual control and classification optimization in conditions of technological processes of beneficiation complexes. CEUR Workshop Proceedings 1356, 2015. Pp. 153-160. (Eng)

10. Internet resource, access method: https://dnep.com.ua/tariffs-business/01.06.2019

11. Internet resource, access method: https://www.ukrrudprom.com/news/25.11.2019

12. Internet resource, access method: https://epravda.com.ua/27.05.2019.

УДК 004.896

\section{РАЗРАБОТКА АЛГОРИТМОВ ДЛЯ НЕЧЕТКОГО УПРАВЛЕНИЯ ЭНЕРГОПОТОКАМИ В УСЛОВИЯХ ПОДЗЕМНОЙ ДОБЫЧИ ЖЕЛЕЗНОЙ РУДЫ}

О. Н. Синчук, докт. техн. наук, А. И. Купин, докт. техн. наук, И. О. Синчук, канд. техн. наук, И.А. Козакевич, канд. техн. наук, И.И. Пересунько

Криворожский национальный университет,

ул. Виталия Матусевича, 11, г. Кривой Рог, 50027, Украина

e-mail: speet@ukr.net

Показана актуальность автоматизированного управления энергетическими потоками в условиях подземной добычи железной руды. Определены: вектор состояния объекта, основные информационные параметры, управляющие воздействия и возмущения. Разработаны алгоритмы автоматизированного управления $c$ использованием нескольких стратегий и каналов управления. Предложены принципь реализации указанных алгоритмов на основе использования нечеткой логики (Fuzzy Logic). Осуществлено моделирование роботьл нечетких контроллеров в среде программного пакета MatLab. Доказана работоспособность алгоритмов функиионирования нечетких регуляторов в условиях одноканального и многоканального управления. Библ. 12 , рис. 8 , табл. 4.

Ключевые слова: автоматизированное управление энергопотоками, Fuzzy Logic, алгоритмы, критерии, система, шахта.

УДК 004.896

\section{РОЗРОБКА АЛГОРИТМІВ ДЛЯ НЕЧІТКОГО КЕРУВАННЯ ЕНЕРГОПОТОКАМИ В УМОВАХ ПІДЗЕМНОГО ВИДОБУТКУ ЗАЛІЗНОЇ РУДИ}

О. М. Сінчук, докт. техн. наук, А. І. Купін, докт. техн. наук, І. О. Сінчук, канд. техн. наук, І. А. Козакевич, канд. техн. наук, I. I. Пересунько

Криворізький національний університет,

вул. Віталія Матусевича, 11, м. Кривий Ріг, 50027, Україна

e-mail: speet@ukr.net

Показано актуальність автоматизованого управління енергетичними потоками в умовах підземного видобутку залізної руди. Визначено вектор стану об'єкта, основні інформаційні параметри, керуючий вплив та обурення. Розроблено алгоритми автоматизованого управління з використанням декількох стратегій $і$ каналів управління. Запропоновано принципи реалізації зазначених алгоритмів на основі використання нечіткої логіки (Fuzzy Logic). Здійснено моделювання роботи нечітких контролерів у середовищі програмного пакету MatLab. Доведено працездатність алгоритмів функиіонування нечітких регуляторів в умовах одноканального $i$ багатоканального управління. Бібл. 12, рис. 8, табл. 4.

Ключові слова: автоматизоване управління енергопотоками, Fuzzy Logic, алгоритми, критерії, система, шахта. 